異型狭心症発作時に括ける左室局所壁運動と左室機能に関する検討

$$
\text { 心エコー法を用いて }
$$

香川医科大学第二内科学 (主任 松尾裕英教授)

水重 克文

\title{
EVALUATION OF REGIONAL AND TOTAL CARDIAC FUNCTION DURING ATTACK OF VARIANT ANGINA
}

Katsufumi Mizushige, MD

The Second Department of Internal Medicine, Kagawa Medical School

(Director : Prof. Hirohide Matsuo)

\begin{abstract}
概要 異型狭心症発作時, 左室壁運動と血行動態との経時的対応から左室動態について検討し た，対象は，冠動脈造影で冠察縮を確認した異型狭心症群12例と, 冠動脈に異常を認めなかつ た対照群 5 例である。 ergonovine maleateを静脈内投与して㹟心発作を誘発し，心エコー法に よつて壁運動の変化を観察した。同時に, 動脈王, 肺動脈圧, 心拍出量, 心電図を連続記録し た.（1)断層心ェコー法によつて異型狭心症群全例で, 冠動脈孪縮部位に相応する左室壁が asynergyを呈するのを観察した。（2)asynergyの出現は心電図ST-T变化の出現よりも106士90 (mean $\pm \mathrm{SD}$ ) 秒先行した。（3）狭心症発作時, Mモード心ェコー図より求めた局所壁平均収縮速 度は, 異型狭心症群では虚血領域で減少 $(30.8 \pm 6.9 \mathrm{vs} 17.2 \pm 7.5 \mathrm{~mm} / \mathrm{sec})$ し, 非虚血領域で 増加 $(27.7 \pm 11.2$ vs $33.0 \pm 13.0 \mathrm{~mm} / \mathrm{sec})$ した。断層心ェコ一図より求めた $\mathrm{mVcF}$ ，相対す る壁がともに非虚血領域である場合增加 $(0.66 \pm 0.09 \mathrm{vs} 0.87 \pm 0.11 \mathrm{circ} / \mathrm{sec})$ し，一方が虚血 領域である場合減少 $(0.60 \pm 0.12$ vs $0.38 \pm 0.12 \mathrm{circ} / \mathrm{sec})$ した. asynergyを呈した領域(\% non contractile segment）が40\%を越克ない例ではstroke indexは変化しなかつた。肺動脈抎張終 期圧は壁運動の変化と平行して上昇 $(8.8 \pm 2.0 \mathrm{vs} 17.0 \pm 3.4 \mathrm{mmHg})$ した。 以上の結果から, 虚血発作時, 虚血領域の機能低下に対して非虚血領域は前負荷の增加にともなつて機能六進し, 虚血領域が狭い場合にはかかる代償的機序によつて心缄全体としての機能は保たれるるのと考 亲らた。
\end{abstract}

Prinzmetalらによつて最初に記述された異型 狭心症が冠動脈挛縮に起因る一過性心筋虚血に より発症することが，冠動脈造影法によつて明ら かにされてきた ${ }^{12)}$. さらに, ergonovine maleate (以下EMと略す) 投与によつて自然発作と注济同 様の狭心発作の誘発が容易となつたことか $ら^{3) 4)}$, 本剂負荷時に心エコ一法5), RI法6)を施行す ることによつて狭心発作時に和ける心筋局所血流 量の減少と, これに伴ら心䁍局所壁運動異常につ

〔昭和58年 1 月 31 日受稿〕
いての報告がなされている。本た，狭心発作時の 左室機能に関して，血行動熊の变化から評価した 報告7)8 女見られる。しかて，現在までのところ血 行動態と局所壁運動とを対応させた検討は報告さ れていない。すた，虚血発作時に冠静脈洞での乳 酸産生が認められ急性心筋梗塞に匹敵するほどの 心筋虚血であることが報告9されてきた。したが つて, 異型狭心症の虚血発作時局所壁運動や血行 動熊を把握することは，心筋梗塞急性期に和ける 壁運動や左室機能を理解する上でも興味深い。

本研究では，EM投与に上る狭心発作誘発時に 
表 1. 対象. 異型狭心症群 $(1 － 12)$ 扎よび対照群 $(13 \sim 17)$.

\begin{tabular}{|c|c|c|c|c|c|c|}
\hline & & & Age & Sex & Asynergy & Sites of Spasm \\
\hline \multirow{12}{*}{$\begin{array}{l}\text { Variant } \\
\text { Angina }\end{array}$} & $t 1$. & Y.S. & 31 & M & ant.w & LADprox. \\
\hline & & $\mathrm{K} \cdot \mathrm{I}$. & 51 & M & IVS & LADprox. \\
\hline & 3. & M.S. & 56 & $\mathrm{M}$ & IVS & LADprox., RCAmid. \\
\hline & & $\mathrm{T} \cdot \mathrm{M}$. & 43 & M & $\inf . W$ & RCAprox., col1at. $(+)$ \\
\hline & & $\mathrm{T} . \mathrm{K}$. & 49 & M & $\inf . W$ & RCAprox., LCXprox. \\
\hline & & $\mathrm{T} \cdot \mathrm{K}$. & 50 & $\mathrm{M}$ & inf.W & RCAprox., LCXprox. \\
\hline & & $M \cdot M$. & 53 & M & inf.W,post. $W$ & RCAprox., LCX (PL) \\
\hline & & $\mathrm{Y} . \mathrm{H}$. & 55 & M & inf. W, post. W & RCAmid., LCXmid. \\
\hline & & $\mathrm{H} . \mathrm{K}$. & 57 & $\mathrm{M}$ & $\inf . \mathrm{W}$ & RCAprox. \\
\hline & 10. & T.F. & 61 & $\mathrm{M}$ & $\inf . W$ & RCA ( 4 PD), LCXprox. \\
\hline & 11 . & $\mathrm{S} . \mathrm{K}$. & 61 & M & inf.W, post.W & RCAmid., LCX (PL) \\
\hline & 12 . & $\mathrm{K} \cdot \mathrm{K}$. & 57 & M & post.W & $\operatorname{LCX}(O M)$ \\
\hline \multirow[t]{5}{*}{ Contro1 } & 13. & Y. H. & 40 & M & - & - \\
\hline & 14. & $\mathrm{H} . \mathrm{F}$. & 43 & M & - & - \\
\hline & 15. & M.o. & 55 & M & - & - \\
\hline & 16. & $\mathrm{H} . \mathrm{H}$. & 56 & $F$ & - & - \\
\hline & 17. & C.N. & 62 & $\mathrm{~F}$ & $=$ & - \\
\hline
\end{tabular}

おける左室機能について解析を試み，左室局所壁 運動と血行動態とを経時的に対応させて，特に局 所壁機能との関連に招いて検討した。

\section{対象}

対象はEMを静脈内投与して狭心発作を誘発し 之た異型狭心症群12例（全例男，年令31 61才， 平均52才）である（表 1 ，症例 1 ～12）。京た，安 静時胸痛を主訴とするもEM投与にて狭心発作を 誘発しえず，正常冠動脈像を呈した 5 例(男 3 例， 女 2 例，年令 $40 ６ 2$ 才，平均 51 才）を対照群とし た（表 1 , 症例13 17).

\section{方 法}

まず安静仰臥位にて心臟カテーテル法を施行 し，その際EM $0.1 \mathrm{mg}$ ずつを約 3 分毎に狭心痛誘 発まで，もしくは最大量 $0.4 \mathrm{mg}$ をで静脈内投与 (bolus injection) した。狭心発作出現に際して左 右冠動脈を抂注同時に造影して冠挛縮を確認し た。

ついで心臓カテーテル施行後数日以内に，同一 時間带，同一場所，同一投与法にてEMを再投与 し，心エコー法による狭心発作に伴ら心臓局所壁
運動の変化を観察した。断層心エコー図は心尖部 からビームを投与して，発作時冠動脈造影によつ てあらかしめ証明した冠挛樎部位和よび心電図 ST変化を認めた誘導部位から予想される虚血領 域を含むよ $5 に$, 左室造影RAO相当断面もしくは LAO相当断面を選択し，いずれに和いても可能な 限り心葴全周を捕珿する心長軸断面とした。 $\mathrm{M}$ モード心ェュー図は第 3〜4 肋間胸骨左縁より, 同様に予想される虚血領域を貫く方向に超音波 ビームを投入して記録した。断層心エコ一因は VTRに，Mモード心エュー図はstrip chartにそれ ぞれコントロール時の記録を行ない，次いでEM を注入後 30 秒每に連続記録した。

局所壁機能を評価するために以下の指標を経時 的に算出した，VTR収録した断層心エコ一図か ら，㹡張終期像，収縮終期像を重ねて心内膜面の トレースを行ない，これからそれぞれの時相に拉 ける通常の左室短軸径（僧帽弁弁尖レベルで心長 軸に直交する左室径) を計測して，動脈王波形か ら求めた左室駆出時間とからmean rate of cir cumferential shortening $(\mathrm{mVcF})$ に相当する値 
を求めた，Mモード心ェコー図からは虚血領域, 非虚血領域のexcursionを測定してmean systolic velocity $(\mathrm{mSV})$ を求めた。すなわち,

$$
\begin{aligned}
& \mathrm{mVCF}=\frac{\text { LVEDD }- \text { LVESD }}{\text { LVEDD } \times \mathrm{ET}} \\
& \mathrm{mSV}=\frac{\text { LVE }}{\mathrm{ET}}
\end{aligned}
$$

LVEDD : left ventricular end-diastolic dimension

LVESD : left ventricular end-systolic dimension

ET : ejection time

LVE : excursion of left ventricular wall として両指標を算出した.

虚血領域の広さの評価は, asynergyの領域すな わちnon contractile segment (NCS) の左室壁全 周に対する比（\% NCS）で行なつた。
$\% \mathrm{NCS}=\frac{\text { length of asynergy (end-diastole) }}{\text { total circumferencial length (end-distole) }}$ $\times 100$

VTR収録した断層心エコー図での評価は三人 の評者が独立に行ない，その平均を用いた。

なお，使用した装置は，断層心エコー法が日立 メディコ社製EUB-10A，VTRがVictor社製6060, Mモード心ェコー法ならびにstirp chartは，それ ぞれAloka社製SSD-110S, SSZ-91である。

血行動態の变化としては, 動脈圧, 肺動脈圧, 心拍出量を観測した。動脈圧は大腿動脈より直接 的に，肺動脈王は大腿静脈より挿入したSwanGanzカテーテルにてそれぞれ連続的に記録した。 また，心拍出量は熱希釈法によつてコントロール 時 3 回測定の後, $\mathrm{EM}$ 投与開始以後 1 分毎に測定 した.

心電図は，II，III，aVF， $\mathrm{V}_{4 \sim 6}$ 誘導を 6 チャンネ ル心電計にて連続的に記録し，さらに 1 分每に 12

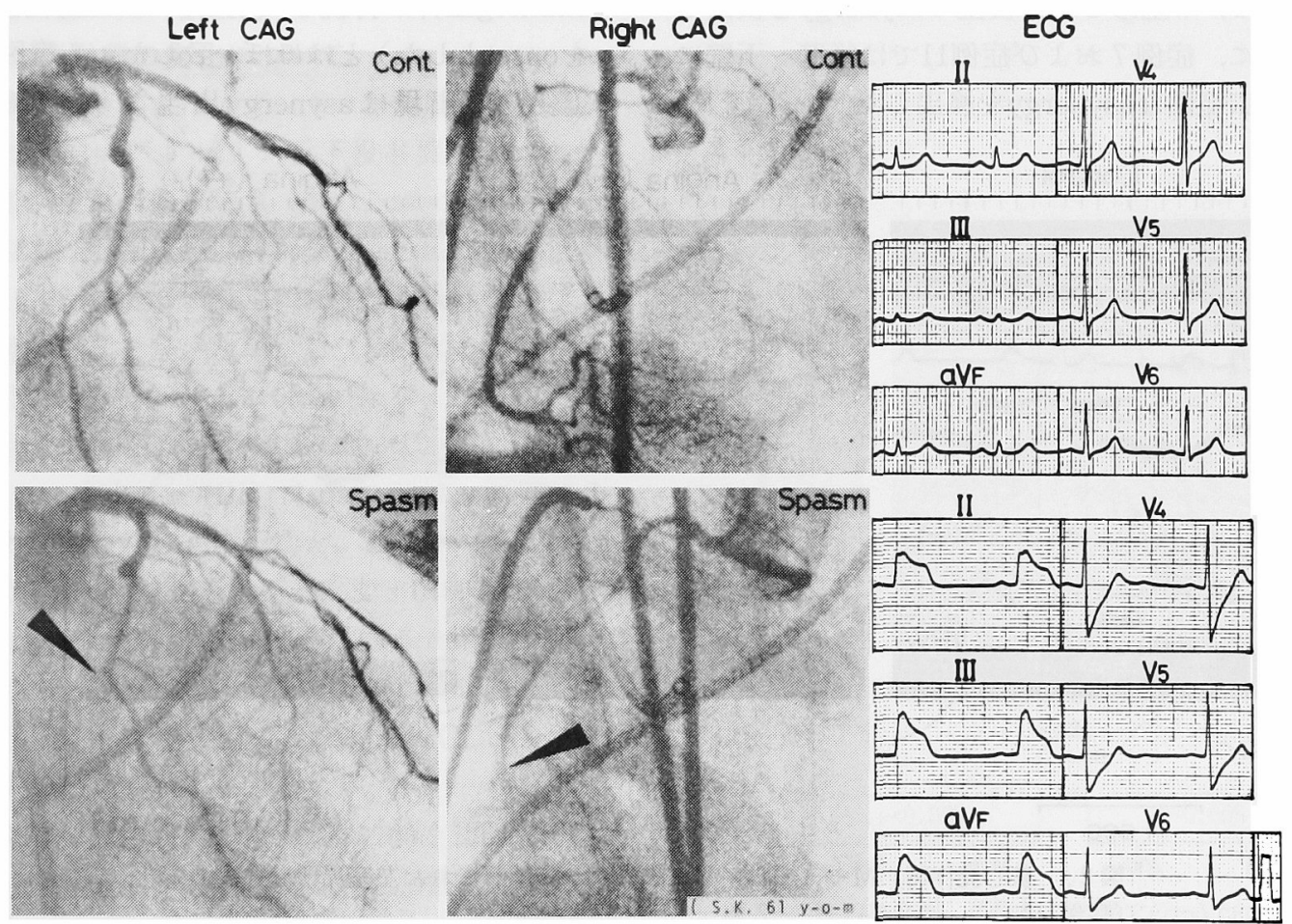

図 1. 狭心発作時, 冠動脈造影および心電図変化（症例11）.

上段がコントロール時である，狭心発作時(下段)，回旋枝後下行枝，右冠動脈中間

部 (矢印) に挛縮を認め，心電図はII, III, aVFでST上昇, $\mathrm{V}_{4} \sim \mathrm{V}_{6}$ でST下降を呈した. 
誘導を記録した。

\section{結果}

1）狭心発作時における冠動脈挛縮部位の検出 と，左室局所壁asynergyの観察

EM投与時狭心発作を誘発しえた全例で冠動脈 造影により冠挛縮部位を確認しえた（図1)．再投 与に際しては，断層心エコー法によつて症例 1 ， 4 - 11でRAO相当断面, 症例 $2,3,12 て ゙ L A O$ 相 当断面を描出し，挛縮を認めた冠動脈の灌流領域 に相応する左室局所壁がasynergyを呈するのを 観察しえた。症例 $1 ， 2$ は左前下行枝のみに挛縮 を認め，前壁，心尖部心室中隔でそれぞれasynergyを検出した。症例 3 は左前下行枝，右冠動脈で 挛縮を認め，心基部一心尖部の広範囲な心室中隔 のasynergyを検出した。症例 4 は右冠動脈の挛 縮, 左前下行枝からの側副血行路を認め，下壁に 限局した狭い領域のasynergyを検出した。症例 5 ～12は右冠動脈，回旋枝の双方もしくは一方に挛 縮を認め, 下壁あるいは後壁でasynergyを検出し た．特に，症例 7 おび症例11では後壁〜下壁に およぶ厷範囲なasynergyを検出した。
Mモード心ェコー法によつても発作時，虚血領 域でのexcursionの低下, 非虚血領域での増加を検 出し克た（図 2）。

心電図は，二度のEM投与時で同一誘導部位に ST-T変化を観察した。症例 $2 ， 6 ， 8$ を除く 9 例 では，ST上昇もしくはST低下を二度の投与時で 同様に認めたが，再投与時で上昇，あるいは低下 の程度はやや軽度の傾向があつた。症例 2 は, 初 回投与時ST上昇, 再投与時ST低下を, 症例 6 は, 初回投与時 $\mathrm{ST}$ 上昇，再投与時 $\mathrm{T}$ 波平担化を，症例 8 は，初回投与時 $\mathrm{T}$ 波平担化，再投与時 $\mathrm{ST}$ 上昇を それぞれ同一誘導部位で認めた。

対照群では，左室壁は全経過を通じて正常な動 きを呈し，心電図ST-T変化も認めなかつた。

2）心室壁運動異常,血行動態变化,心電図変化, および胸痛発現の時間的関係について

$\mathrm{EM}$ 投与時, asynergyの出現時期と肺動脈拡張 終期圧（PAEDP）の上昇時点（呼気時測定で， $2 \mathrm{mmHg}$ 上昇が持続した場合，この上昇開始時点 をonsetとした）とはほぼ一致した。，電図上ST. $\mathrm{T}$ 変化の出現は asynergy出現よりも106土90秒
Control

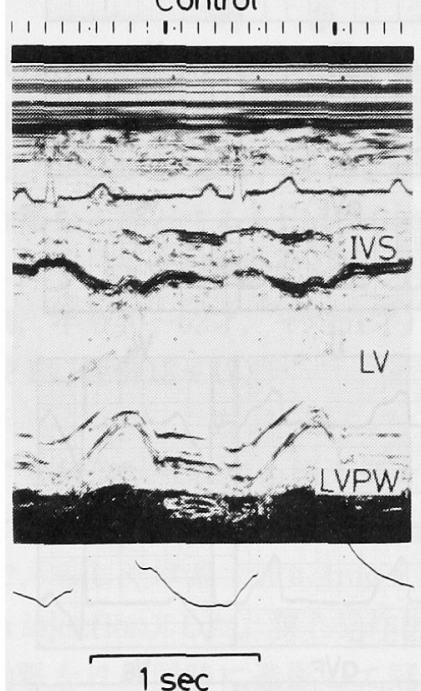

Angina ( + )
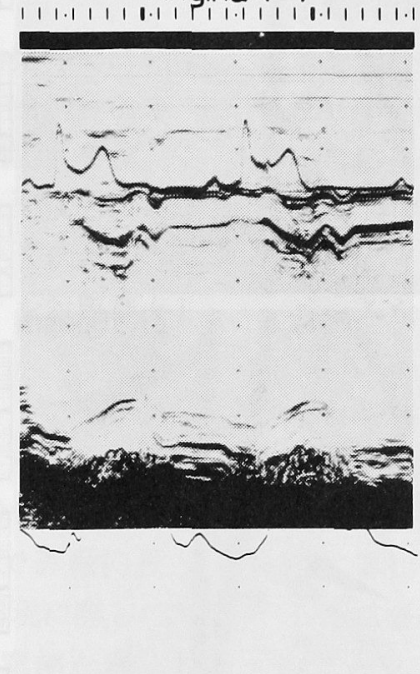

Angina $(++)$

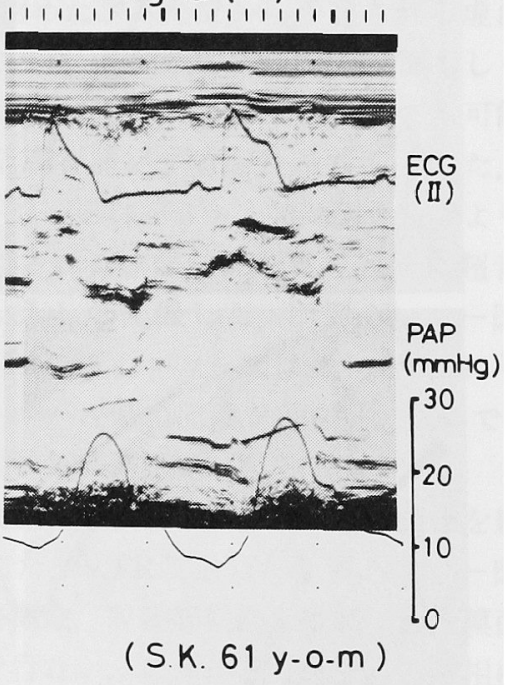

図 2. 狭心発作時, Mモード心ェコー法によつて観察された左室局所壁運動の变化 (症例11).

コントロール時, 左室後壁，心室中隔は正常な動きを呈したが(左)，発作時，後壁 はhypokinesis (中央), akinesis (右)となり，心室中隔はhyperkinesisとなつた。断 㒶心エコー法では，左室後壁から下壁にかけての広範囲なasynergyが観察された。 


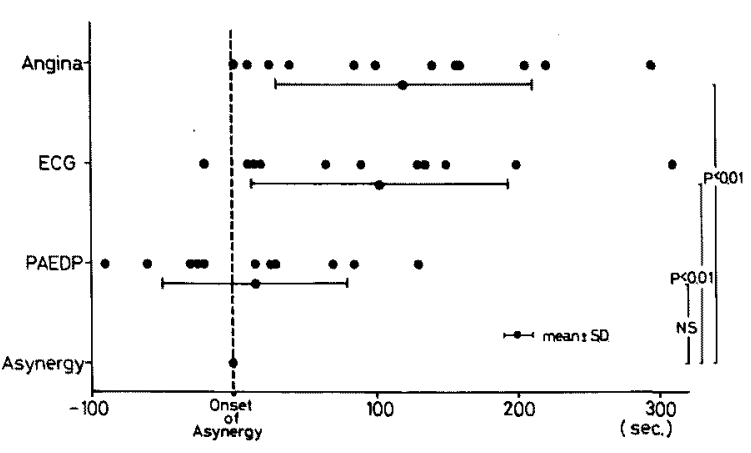

図 3. 㹨発作時, asynergy, 肺動脈抾張終期圧，心 電㘡それぞれの変化の出現, 胸痛発現の時間的関係. Asynergyの出現時点を基準（破線で示す）とした。 asynergyの出現と肺動脈払張終期纴の上界とはほぼ 同時であるが，心電図变化の出現は平均106秒遅れ， anginaの出現はさらに遅れた。

(mean $\pm \mathrm{SD}$, 以下同) 遅れた $(\mathrm{p}<0.01, \mathrm{t}$ test)，胸 痛発現はasynergy出現より119 189 秒荤れ $(\mathrm{p}<$ $0.01, \mathrm{t}$ test），心電図ST-T変化よりもさらに遅れ る傾向にあつた（図 3 ）。

\section{3）血行動態の变化について}

異型狭心症群では, コントロール時と発作寛解 のためニトログリセリン敌下投与直前 asynergy の程度が最大である時点 (max, asynergy時) と

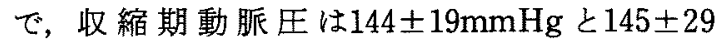

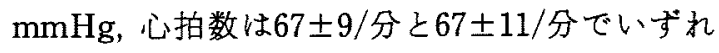
も有意な変化を呈さなかつた（paired t test, 以下 同). PAEDP は8.8 $2.0 \mathrm{mmHg}$ より $17.0 \pm 3.4$ mmHg と増加した $(\mathrm{p}<0.0005)$. Cardiac index (CI), stroke index (SI) はmax. asynergy時に 1 分毎に測定した 3 回の平均と，コントロール時と を対比したところ，それぞれ3. $32 \pm 0.39 \mathrm{l} / \mathrm{min} / \mathrm{m}^{2}$ より $3.32 \pm 0.79 l / \mathrm{min} / \mathrm{m}^{2}, 50.3 \pm 6.8 \mathrm{ml} / \mathrm{beat} / \mathrm{m}^{2}$ より $49.0 \pm 9.3 \mathrm{ml} / \mathrm{beat} / \mathrm{m}^{2}$ と有意な変化を呈さな

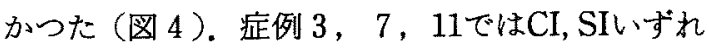
も低下した。

対照群では，収緶期動脈王は $140 \pm 18 \mathrm{mmHg}$ 上 り $154 \pm 19 \mathrm{mmHg}(\mathrm{p}<0.025)$ ，心拍数は62士4/分 上り $66 \pm 6 /$ 分 $(\mathrm{p}<0.025)$ と増加した. PAEDPも $6.8 \pm 2 \mathrm{mmHg}$ より $10.4 \pm 3.2 \mathrm{mmHg}$ 一増加した $(\mathrm{p}<0.0005) . \mathrm{CI}, \mathrm{SI}$ 有意な変化を呈さなかつた

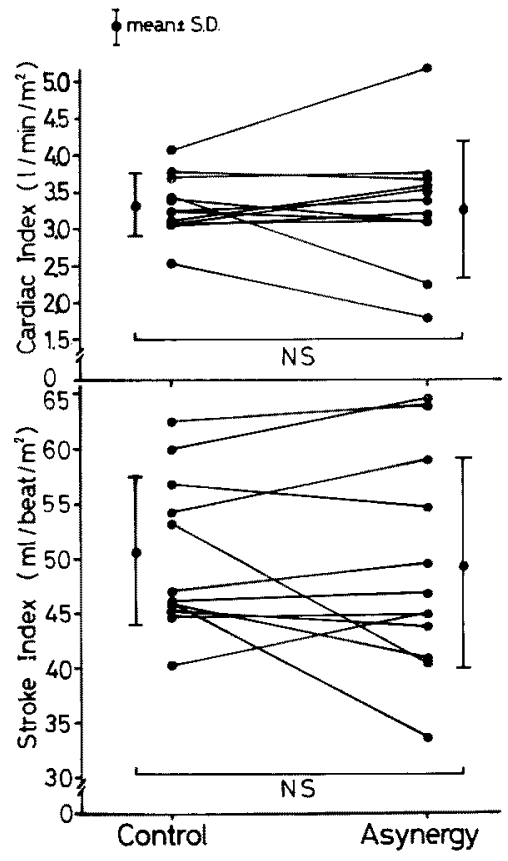

図 4. 狭心発作時, 異型狭心症群でのcardiac index (上), stroke index (下) の変化.
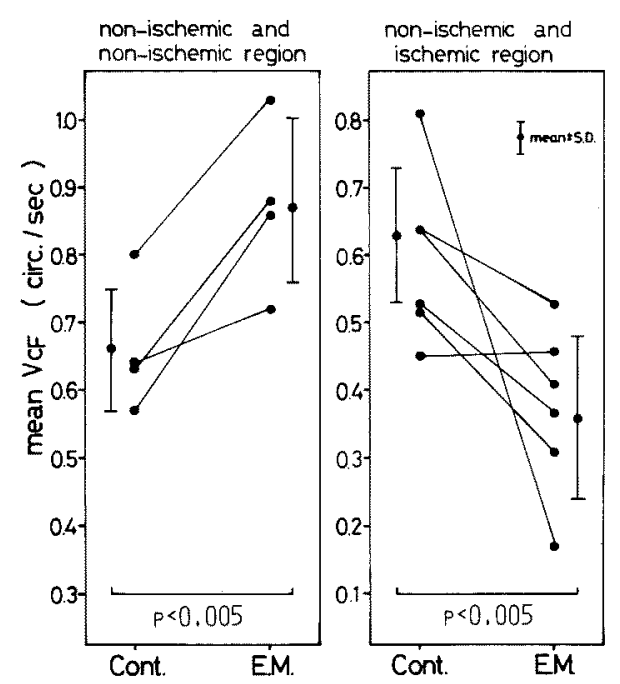

図 5.狭心発作時, 巽型狭心症群での $\mathrm{mVCF}$ 変化. $\mathrm{mVCF}$ を測定した左室短軸径が，いずれる非虚血領 域からなる4例（左）では著明に增加し，一方が虚血 領域からなる6例（右）では低下した。 
表 2. 狭心発作時における血行動態の変化.

\begin{tabular}{|c|c|c|c|c|c|c|c|c|}
\hline \multirow[t]{2}{*}{ patient } & \multicolumn{2}{|c|}{$\begin{array}{l}\text { syst.A.P. }(\mathrm{mmH}) \\
\text { cont. } \mathrm{E} \text {. }\end{array}$} & \multicolumn{2}{|c|}{ H.R. (beat $/ \mathrm{min}$ ) } & \multicolumn{2}{|c|}{ PAEDP (mmHg) } & \multicolumn{2}{|c|}{ S.I. $\left(\mathrm{m} 1 /\right.$ beat $\left./ \mathrm{m}^{2}\right)$} \\
\hline & cont. & E. & cont. & E. & cont. & E. & cont. & E. \\
\hline 1.Y.S. & 102 & 104 & 69 & 70 & 8 & 18 & 46.2 & 47.0 \\
\hline 2.K.I. & 160 & 170 & 63 & 58 & 8 & 14 & 60.1 & 64.7 \\
\hline 3.M.S. & 134 & 144 & 73 & 75 & 6 & 18 & 45.8 & 41.0 \\
\hline 4.T.M. & 152 & 144 & 69 & 69 & 10 & 16 & 44.8 & 44.9 \\
\hline S.T.K. & 136 & 130 & 67 & 66 & 12 & 24 & 54.3 & 59.1 \\
\hline 6.T.K. & 136 & 150 & 57 & 58 & 10 & 16 & 47.2 & 49.6 \\
\hline 7.M.M. & 140 & 108 & 55 & 51 & 10 & 12 & 46.0 & 33.8 \\
\hline 8.Y.H. & 148 & 156 & 72 & 70 & 10 & 22 & 45.5 & 43.9 \\
\hline 9.H.K. & 124 & 114 & 50 & 58 & 10 & 18 & 62.6 & 64.0 \\
\hline 10.T.F. & 164 & 180 & 76 & 75 & 10 & 18 & 40.4 & 45.1 \\
\hline $11.5 . \mathrm{K}$. & 166 & 136 & 65 & 56 & 5 & 12 & 53.2 & 40.5 \\
\hline 12.K.K. & 170 & 208 & 84 & 95 & 6 & 16 & 57.5 & 54.7 \\
\hline \multirow[t]{2}{*}{ meantS.D. } & $144 \pm 19$ & $145+29$ & $67 \pm 9$ & $67 \pm 11$ & $8.8 \pm 2.0$ & $17.0+3.4$ & $50.3 \pm 6.7$ & $49.0 \pm 9.3$ \\
\hline & \multicolumn{2}{|c|}{ NS } & \multicolumn{2}{|c|}{ NS } & \multicolumn{2}{|c|}{$\mathrm{p}<0.0005$} & \multicolumn{2}{|c|}{ NS } \\
\hline 13.Y.H. & 124 & 136 & 64 & 64 & 8 & 12 & 68.5 & 71.9 \\
\hline 14.H.F. & 142 & 164 & 55 & 56 & 4 & 8 & 58.7 & 55.2 \\
\hline $15 . \mathrm{M} . \mathrm{O}$ & 122 & 126 & 60 & 65 & 6 & 8 & 60.4 & 63.9 \\
\hline 16.H.H. & 142 & 170 & 65 & 74 & 6 & 8 & 40.2 & 42.6 \\
\hline 17.C.N. & 172 & 172 & 67 & 71 & 10 & 16 & 53.7 & 48.9 \\
\hline \multirow[t]{2}{*}{ meantS.D. } & $140 \pm 18$ & $154 \pm 19$ & $62 \pm 4$ & $66 \pm 6$ & $6.8+2.0$ & $10.4 \pm 3.2$ & $56.3 \pm 9.4$ & $56.5 \pm 10.4$ \\
\hline & \multicolumn{2}{|c|}{$p<0.025$} & \multicolumn{2}{|c|}{$p<0.025$} & \multicolumn{2}{|c|}{$p<0.0005$} & \multicolumn{2}{|c|}{ NS } \\
\hline
\end{tabular}

syst.A.P.: systolic Arterial Pressure, H.R.: Heart Rate, PAEDP: Pulmonary Arterial end-diastolic Pressure, S. I.:Stroke Index cont.:at control state, E.:after injection of Ergonovine Maleate statistical analysis:paired $t$ test

(表 2).

\section{4）左室局所壁機能の变化おょU゙虚血領域の広} さについて

症例 $1 ， 5$ 除く10例で心ェコー図にてmVcF， $\mathrm{mSV}$ の測定が可能であつた。心尖部中隔に asynergyを認めた症例 2 ，下壁の限局した領域に asynergyを認めた症例 4，6，9では， $\mathrm{mVcF}$ いずれも非虚血領域のみを貫くビーム方向にて短 軸径を算出して括り，EM負荷後 $0.66 \pm 0.09 \mathrm{circ} /$ $\sec$ より $0.87 \pm 0.11 \mathrm{circ} / \mathrm{sec}$ に增加した（p< 0.005). 症例 $3,7,8,10,11,12$, では断層 心エコー図上の短軸径計測の一側が虚血領域に該 当し, $\mathrm{mVCF}$ はEM負荷後 $0.60 \pm 0.12 \mathrm{circ} / \mathrm{sec}$ より
$0.38 \pm 0.12 \mathrm{circ} / \mathrm{sec} に$ 低下した $(\mathrm{p}<0.005$ )（図 5 ， 表 3 ).

異型狭心症群より求めた虚血領域 8 カ所での $\mathrm{mSV}$ は, $30.8 \pm 6.9 \mathrm{~mm} / \mathrm{sec}$ よ $17.2 \pm 7.5 \mathrm{~mm} /$ seck低下し $(p<0.005)$, 非虚血領域 7 カ所では

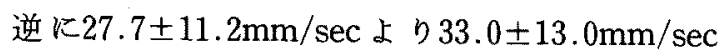
に增加した $(\mathrm{p}<0.005)$ (図 6 , 表 3 ).

冠孪縮の誘発をみなかつた対照群 5 例, 7 力所 の壁でのmSVはEM $0.4 \mathrm{mg}$ 投与後 $32.4 \pm 6.5 \mathrm{~mm} /$ $\sec$ より $31.7 \pm 6.9 \mathrm{~mm} / \mathrm{sec}$ と有意な変化を呈さ なかつた。

断風心エコー図から計測した\% NCSは, CI, SI いずれも低下した症例 $3 ， 7 ， 11 に$ 打いて，それ 


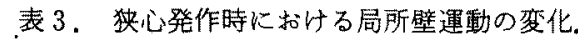

\begin{tabular}{|c|c|c|c|c|c|c|c|c|}
\hline \multirow{3}{*}{ patient } & \multicolumn{4}{|c|}{$\mathrm{mv}_{\mathrm{CF}}(\mathrm{circ} / \mathrm{sec})$} & \multicolumn{4}{|c|}{$\mathrm{mSV}(\mathrm{mm} / \mathrm{sec})$} \\
\hline & \multicolumn{2}{|c|}{$\mathrm{N}-\mathrm{N}$} & \multicolumn{2}{|c|}{$\mathrm{N}-\mathrm{I}$} & \multicolumn{2}{|c|}{$\mathrm{N}$} & \multicolumn{2}{|c|}{ I } \\
\hline & cont. & E. & cont. & E. & cont. & E. & cont. & E. \\
\hline 1.Y.S. & - & - & - & - & - & - & - & - \\
\hline 2.K.I. & 0.64 & 0.72 & - & - & - & - & 20.6 & 11.4 \\
\hline 3.M.S. & - & - & 0.81 & 0.17 & 29.8 & 33.3 & 21.2 & 9.1 \\
\hline 4.T.M. & 0.80 & 1.03 & - & - & $\begin{array}{l}30.4 \\
51.8\end{array}$ & $\begin{array}{l}32.3 \\
62.3\end{array}$ & - & - \\
\hline 5.T.K. & - & - & - & - & - & - & - & - \\
\hline $6 . \mathrm{T} . \mathrm{K}$ & 0.63 & 0.88 & - & - & - & - & 36.7 & 32.3 \\
\hline 7.M.M. & - & - & 0.64 & 0.53 & 19.3 & 18.2 & 42.3 & 16.4 \\
\hline 8.Y.H. & - & - & 0.66 & 0.36 & 26.4 & 30.5 & 31.3 & 10.2 \\
\hline 9.H.K. & 0.57 & 0.86 & - & - & - & - & 32.8 & 20.3 \\
\hline 10.T.F. & - & - & 0.52 & 0.31 & - & - & 33.1 & 24.3 \\
\hline 11.S.K. & - & - & 0.64 & 0.41 & 14.7 & 23.6 & 28.5 & 13.9 \\
\hline 12.K.K. & - & - & 0.53 & 0.37 & 21.4 & 31.0 & - & - \\
\hline
\end{tabular}

mean+S.D. $0.66+0.09 \quad 0.87 \pm 0.11 \quad 0.60 \pm 0.12 \quad 0.38+0.12 \quad 27.7 \pm 11.2 \quad 33.0 \pm 13.0 \quad 30.8 \pm 6.9 \quad 17.2 \pm 7.5$

$p<0.005 \quad p<0.005 \quad p<0.005 \quad p<0.005$

\begin{tabular}{|c|c|c|c|c|c|c|c|c|}
\hline 13.Y.H. & - & - & - & - & 34.3 & 30.7 & - & - \\
\hline 14.H.F. & - & - & - & - & $\begin{array}{l}24.1 \\
43.1\end{array}$ & $\begin{array}{l}26.6 \\
43.1\end{array}$ & - & - \\
\hline $15 . \mathrm{M} . \mathrm{O}$ & - & - & - & - & $\begin{array}{l}38.0 \\
23.7\end{array}$ & $\begin{array}{l}37.1 \\
20.3\end{array}$ & - & - \\
\hline 16. H. H. & - & - & - & - & 30.4 & 29.5 & - & - \\
\hline 17.C.N. & - & - & - & - & 33.4 & 34.5 & - & - \\
\hline \multirow[t]{2}{*}{ meants. D. } & & & & & $32.4 \pm 6.5$ & $31.7 \pm 6.9$ & & \\
\hline & & & \multicolumn{6}{|c|}{ NS } \\
\hline
\end{tabular}

${ }^{m V_{C F}}$ :mean rate of circumferential shortening, mSV:mean systolic velocity, N-N:non-ischemic region and non-ischemic region, N-I:non-ischemic region and ischemic region, N:non-ischemic region, I:ischemic region statistical analysis:paired t test
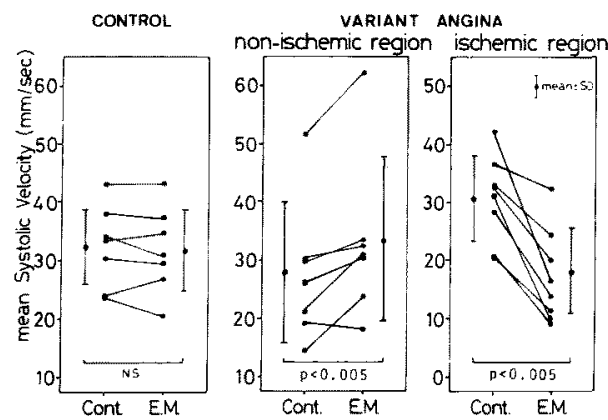

図 6, 狭心発作時, mSVの变化. 健常対照群 7 力所の 壁では有意な変化を諗めず（左），異型狭心症群では， 非虚血領域で增加（中央），虚血領域では低下（右）し た。

昭和58年 8 月 10 日
ぞれ $50 \% ， 46.5 \% ， 54.2 \%$ いずれも40\%をこ克 ていた（図 7).

異型狭心症群で断層心エコー図から計測した拡

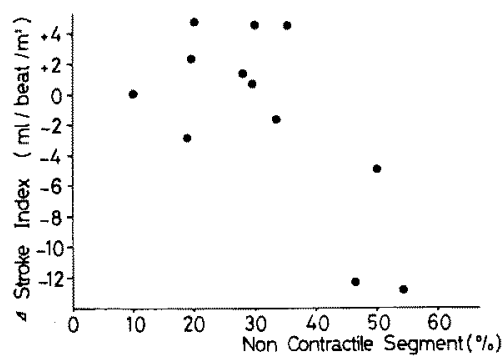

因 7. 虚血領域の大きさ (\% NCS) と狭心発作時の stroke index変化量との関俰。 \% NCSが $40 \%$ を越光る 例でstroke indexは著明に低下した。 
張終期左室短軸径は $44.3 \pm 6.0 \mathrm{~mm}$ より $47.0 \pm 5.5$ $\mathrm{mm}$ に狭心発作時増加した $(\mathrm{p}<0.005)$.

\section{考 案}

1）EMによる冠毫樎誘発の再現性，および発作 時冠窂縮部位と心室壁運動異常領域との対 応性に関する検討

異型狭心症では，EMの静脈内投与によつて冠 動脈の特定部位に冠挛縮が認められることが冠動 脈造影法により証明されてきだ34. EMで誘発さ れた冠挛縮と自然発作時冠挛縮の類似性について はCurry らかが症状, 心電図ST-T変化の程度・誘導 部位, 左室血行動態, 冠動脈造影所見について対 比し，EMによる狭心発作発現は自然発作とほば 同様であることを報告した。

また，Yasue $ら^{10)} は$ treadmill exercise testによ つて冠挛縮を誘発して, 早朝の方が午後よりる高 頻度に誘発しえたことから，冠挛縮の出現に日内 変動があることを報告している，そこで，本研究 では心䁍カテーテル施行時に扣ける冠挛縮誘発 と, 心ェコー法施行時での再誘発とで再現性よく 狭心発作を得るために, 心欌カテーテル施行後数 日以内に, 同一時間帯, 同一場所, 同一方法で再 誘発を試みた。心臓カテーテル施行時, 再誘発時 に括いて，狭心痛の性状が同一で，心電図ST低下 あるいは上昇はやや程度に差があつたが同一誘導 部位でST·T变化の出現を観察した。このことか ら冠挛樎が冠動脈の限局した一定部位で誘発さ れ，これに伴い一定した心葴局所壁で再現性をも つて虚血が䒴起されたと考えられる.

異型狭心症発作時に就ける局所壁運動について は, Widlansky $5^{5)}$ がisometric hand-grip stressに よつて左前下行枝に冠挛縮を認めた症例で，M モード心ェコー法を用いて心室中隔が hypo. kinesisを呈したことを報告した，本研究での12例 の異型狭心症例に打いても，左前下行枝に挛縮を 認めた 3 例では前壁もしくは心室中隔に, 右冠動 脈あるいは回旋枝に挛縮を認めた症例では下壁あ るいは後壁に，断層心エコー法により asynergyを 認め，冠動脈挛縮部位とasynergy領域とはよく対 応していた。したがって，心エコー法を用いて左
室壁運動を観察することによつて，毟縮を来した 冠動脈の灌流領域を把握し立，発作時左室局所機 能についても充分評価しらるものと思われた。

2）虚血発作時における心室壁運動異常，血行動 態变化，心電図变化の時間的関係に関する検 討

心筋虚血を示す指標として，心電図ST-T変化 が最も一般的であるが，時間的に心笳虚血の発生 と心電図変化の出現とは必ずしも一致しないとさ れる、すなわち, Maseriら 23 は異型狭心症 5 例で自 然発作に際してpeak dp/dtの低下が心電図ST-T 変化よりも6〜36秒先行することを報告してい る、また, Millerら"1イヌでの冠動脈結紫実験で enddiastolic muscle length, systolic shortening を測定して, 心電図ST変化の出現と対比し, enddiastolic dilatation, systolic shorteningの減少が 心電図変化よりも20秒先行することを報告した。

本研究では, asynergyの出現がST-T変化より す平均106秒先行し, 電気生理学的変化よりもょり 早期に，あるいはより軽度の心筋虚血で壁運動が 障害されるものと考えられる。

3）虚血発作時における左室局所壁機能に関す 了検討

Nieminenら ${ }^{12}$ は急性心筋梗塞例での局所壁機 能を評価するためにMモード心ェュー法を用い て、ビーム方向を種々に变化させて前壁4 segments, 後壁3 segmentsの壁運動の振幅を計測し て,これらの総和から心臟全体としての機能評価 を行ない，臨床症状とよい相関を認めたことを報 告した，本研究では，冠挛縮に伴う急激な心能虚 血に際して，局所壁運動の変化を $\mathrm{Mモード心ェ}$ コー図から求めた $\mathrm{mSV}$, 断層心エコ一図から求め たmVcFによって心室壁を segmentに細分せず， 非虚血領域，虚血領域に大別して評価した。

Vatnerら ${ }^{13}$ はイヌを用いた実験で，冠動脈血流 を徐々に減少させて虚血領域の壁運動を ultrasonic elementで観察し，冠血流量の減少と 同時に壁運動が障害され，以後壁運動の障害は指 数関数的に進行していくことを報告した。本研究 でも図 2 に示したよりに hypokinesisから 
akinesisへと虚血領域の壁運動障害は急激に進行 した.

一方, 非虚血領域の動態についてTheroux $5^{14)}$ はUltrasonic elementを用いたイヌの冠動脈閉塞 実験で, 冠動脈閉塞後systolic shorteningが虚血 領域で減少するのに対して非虚血領域で逆に増加 することを報告した．ところが，Wyattら ${ }^{15)}$ の報告 では非虚血領域でも systolic shoteningの低下が 観測されたとして拈り，虚血発作時に和ける非虚 血領域の動態についてはな和不明な点も多い。

本研究では，発作時虚血領域でのmSVは低下 し，非虚血領域では増加した。これは非虚血領域 が，虚血発作に伴ら虚血領域の局所壁機能低下に 対して機能过隹したことを示している。ささらに， mVcFは asynergyの存在しない心室では contractilityを示す指標とされているが，本研究 におけるようにasynergyのある場合には，心室全 体としてのinotropic stateを示すと考えるより は，相対する局所壁双方の運動の合計を示すと解 釈される、すなわち，断層心ェコー法にて左室局 所壁運動をより詳細に把握すると，ここで算出し た $\mathrm{mVCF}$ は次のように理解される。左室短軸径を 求めるに際して，症例 $3 ， 8 ， 10,11,12 て ゙ は$ 相 対する壁は非虚血領域と虚血領域とからなつてお $\eta, \mathrm{mVcF}$ は虚血発作時低下し，一方症例 2，4， 6，9に扣いては相対する壁は両者とも非虚血領 域で， $\mathrm{mVCF}$ は著明に増加した。すなわち前者で は，虚血領域での局所壁機能低下が非虚血領域に

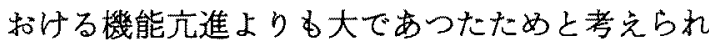
る.

Maseriら ${ }^{6} は ， R I$ 法を用いて異型狭心症例で自 然発作時に括ける冠血流量を測定した結果，虚血 領域では冠血流量は減少するのに対して，非虚血 領域では逆に増加したのを観察して和り，狭心発 作時冠血流分布の変化からも非虚血領域の機能六 進を示唆している。

虚血発作時での非虚血領域の機能六進の要因之 $し て ， i)$ 前負荷増大, ii)局所心筋収縮力増加が考 えられる.Theroux $5^{14)}$ は冠動脈結禁時非虚血領 域での搪張終期筋長が堌加することから，前負荷
増大が要因であるとした。一方，Vokonasら ${ }^{16)}$ は Therouxらと同様の方法で害験を行ない，非虚血 領域での拡張終期筋長が変化しないとしたが，彼 らの場合は左室拡張終期圧も増加せず，冠動脈結 禁から長時間を経ての観察であつた。

本研究では，虚血発作時PAEDPが急激に上昇 したこと, 非虚血領域でのmSV増加とPAEDP上 昇とが同時に出現したこと，拡張終期左室径が拡 大したこと，一方，心拍数，収縮期体動脈圧が有 意な变化を呈さなかつたこと，EM投与に際して 対照群ではmSVは変化せず壁運動に対するEM の直接作用は認めないことなどから inotropic stateの変化は考党がたく，前負荷の増大が非虚血 領域の機能六進に関与したものと考克られる。

EMは末梢の抵抗血管に作用して軽度に血圧を 上昇させることが知られている。本研究では，対 炤群でEM投与時収縮期体動脈圧の軽度上昇を認 めたが，異型狭心症群に招いてはコントロール時 と EM投与時とで動脈仕に有意差を認めていな い，一方肺動脈仕は対照群で軽度上昇を認めるの みであつたのに対して，異型狭心症群では急激に 上昇した。これは，肺動脈拡張終期圧の上昇が $\mathrm{EM}$ による肺末梢血管抵抗の増大によるのではなく， 虚血にともなら左室コンプライフンスの低下 ${ }^{17)}$, すなわち虚血領域に打ける虚血時壁伸展性の障害 によりもたらされたものと考えられる。ささに， このような左室拡張終期圧の上昇が非虚血領域に 対しての前負荷増大として作用し，局所壁運動を 六進させたものと解される。

4）虚血発作時,左室トータル機能に関する検討

虚血発作時に打ける心拍出量の变化について

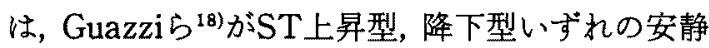
時狭心症例でもCIが低下したことを示した。しか し, Paganiら゙はイヌを用いた冠動脈結禁実験で, 左前下行枝もしくは回旋枝一方のみの結惄では SIは保たれたが，左冠動脈主幹部の結禁では著明 に減少したことから，虚血領域の広さが虚血発作 時の心機能に関して重大な意義を有することを報 告した。本研究でも，\% NCSが40\%を越えた例で はSIが急激に低下した。 
さらに，冠血流量と左室機能との関係では，小 岩ら ${ }^{199}$ がイヌでの冠動脈結禁実験で冠血流量を 徐々に減少させ, 虚血の程度に応じた左室機能の 検討を行ない，冠血流量が減少する過程で前負荷 の増大により左室機能が保たれる時期があること を示した。すなわち，虚血発作時左室機能に影響 を括よ深吉因子として，i 虚血領域の大きさ，ii） 虚血領域の機能低下の程度, iii)非虚血領域の機能 元進の程度が挙げられる。Hegerら ${ }^{20)}$ はこれらの 因子を加味して，断層心ェュー法を用いて急性心 筇梗塞で心坓壁を9 segmentsに, 壁運動の亢進, 低下の程度を5 gradeに分けてこれらを合計して 求めたscore (wall motion index) と臨床的重症 度とを対比して，良好な相関を認めている。本研 究では，虚血領域機能低下がhypokinesisもしくは akinesisであつてその程度に大差がなく，そのた め虚血領域の大きさが発作時心機能を決定する主 要因子となつた。したがつて，虚血領域が40\%を 越える例でSIの低下が認められ，それ以下の例で は前負荷の増大に伴ら非虚血領域の代償的機能六 進によつてSIが保たれたと考劣られた。

\section{結論}

1）異型狭心症例にEMを投与して冠挛縮を誘 発し，全例で挛縮部位に相応した左室局所壁の asynergyを観测しえた。

2) Asynergyの出現は心電図ST-T変化ょりる 106士90秒先行した.

3）虚血発作時, 虚血領域が40\%を越えない例で は, 前負荷の増加に伴う非虚血領域の機能六進に よつてSIが保たれた。

謝辞 稿を終えるにあたり終始御鞭撻, 御助言をいたた いた大阪大学第一内科阿部裕教授，大阪警察病院心䐵七 ンター 児玉和久部長に感謝いたしすす。

\section{文献}

1) Oliva $\mathrm{PB}$, et al: Coronary arterial spasm in Prinzmetal angina. Documentation by coronary arteriography. New Engl J Med 288: 745, 1973.

2) Maseri A, et al : Coronary artery sapsm as a cause of acute myocardial ischemia in man. Chest $68: 625,1975$.

3) Schroeder JS, et al: Provocation of coronary spasm with ergonovine maleate. New test with results in 57 patients undergoing coronary arteriography. Amer J Cardiol 40: 487, 1977.

4) Curry RC, et al: Similarities of ergonovineinduced and spontaneous attacks of variant angina. Circulation $59: 307,1979$.

5) Widlansky $S$, et al: Coronary angiographic, echocardiographic, and electrocardiographic studies on a patient with variant angina due to coronary artery spasm. Amer Heart J $90: 631$, 1975.

6) Maseri A, et al: Transient transmural reduction of myocardial blood flow, Demonstrated by Thallium-201 scintigraphy, As a cause of variant angina. Circulation $54: 280,1976$.

7) Curry RC, et al: Effects of ergonovine in patients wih and without coronary artery disease. Circulation $56: 803,1977$.

8) Pagani $M$, et al: Initial myocardial adjustments to brief periods of ischemia and reperfusion in the conscious dog. Circ Res 43:83, 1978.

9) Goldberg S, et al: Coronary hemodynamic and myocardial metabolic alterations accompanying coronary spasm. Amer J Cardiol $43: 481,1979$.

10) Yasue $\mathrm{H}$, et al: Circadian variation of exercise capacity in patients with Prinzmetal's variant angina: Role of exercise-induced coronary arterial spasm. Circulation $59: 938,1979$.

11) Miller MM, et al: Myocardial ischemia. Relationship between local flow, function and ST-segment elevation. Europ I Cardiol 10:7, 1979.

12) Nieminen $M$ and Heikkilä $J$ : Echoventriculography in acute myocardial infraction. III. Clinical correlations and implication of the noninfarcted myocardium. Amer J Cardiol 38 : 1, 1976.

13) Vatner SF : Correlation between acute reductions in myocardiol blood flow and function in conscious dogs. Circ Res 47: 201, 1980.

14) Theroux $P$, et al: Regional myocardial function in the conscious dog during acute coronary occlusion and responses to morphine, propranolol, nitroglycerin, and lidocaine. Circulation $53: 302,1976$.

15) Wyatt HL, et al: Functional abnormalities in nonocculuded regions of myocardium after experimental coronary artery occlusion and its modification by pharmacologic agents in the 
dog. Circ Res 35: 896, 1974.

16) Vokonas PS, et al : Experimental myocardial infarction. XIII. Dynamic changes in segmental mechanical behavior of infarcted and non-infarcted myocardium. Amer J Cardiol 37 : 853, 1976.

17) Gaasch WH, et al: The influence of acute alterations in coronary blood flow on left ventricular diastolic compliance and wall thickness. Europ J Cardiol, Suppl 7, p147, 1978.

18) Guazzi $H$, et al: Left and right heart haemodynamics during spontaneous angina pectoris. Comparison between angina with ST segment depression and angina with ST segment elevation. Brit Heart J $37: 401,1975$.

19）小岩堨郎，他：左前下行技 -中隔枝冠血流量減少 の左室機能に及ほす影響。心䁍 $13: 291 ， 1981$.

20) Heger JJ, et al: Cross-sectional echocardiographic analysis of the extent of left ventricular asynergy in acute myocardial infarction. Circulation 61 : 1113, 1980. 